\title{
As veredas, o sertão, a vida: a dinâmica da fé de Riobaldo a partir de Paul Tillich
}

\author{
Viviane de Sousa Rocha*
}

\section{RESUMO}

Este trabalho quer fazer emergir aspectos da fé de Riobaldo, ou seja, como a fé aparece nesse personagem tão peculiar, tão ambíguo, paradoxal, um ser tão ímpar? A questão surgiu a partir da leitura do livro de João Guimarães Rosa e da leitura de Paul Tillich (1985) na Especialização em Ciências da Religião. O livro de Tillich, Dinâmica da Fé (1985) será referência teórica, utilizado para refletir e estudar a fé. Assim, a partir dessa leitura, busca-se identificar a fé do personagem Riobaldo. O objetivo geral é investigar um recorte do livro, isto é, o personagem Riobaldo e sua fé, na narrativa de Grande Sertão: Veredas. Os objetivos específicos consistem em analisar a partir da definição de fé elaborada por Paul Tillich (1985), aspectos religiosos e relações com o sagrado e o transcendente presentes na fé do místico e filósofo Riobaldo. A metodologia será a pesquisa bibliográfica. Por meio de revisão de literatura, busca-se aprofundar a leitura da obra, com alguns autores e pesquisadores, tais como Antonio Candido e Walnice Galvão. Serão abordadas as questões relativas à fé do sertanejo. A questão que nos moveu durante a pesquisa consiste na existência da fé em meio à dúvida. O trabalho resultou na continuação dos estudos no mestrado, tendo como referencial teórico Paul Tillich e dois contos de Rosa como objeto de pesquisa. Palavras-chave: Fé, Riobaldo, Tillich.

* Mestranda em Ciência da Religião (UFJF). Especialista em Ciência da Religião (UFJF). Licenciada em Letras pela UFJF (1999), E-mail: visrocha1977@gmail.com. (Currículo Lattes ID Lattes: 2786593017865337) https://orcid.org/0000-0002-2662-3826 


\title{
PATHWAY, BACKWOODS, AND LIFE: RIOBALDO'S FAITH
}

\begin{abstract}
This paper highlights some Riobaldo's faith aspects. How does such a peculiar, ambiguous, paradoxical, and unique character manifest his faith? The question arose during the author's post-graduation research, after reading The Devil to Pay in the Backlands (1956), by João Guimarães Rosa, and Dynamics of Faith, by Paul Tillich (1985). Tillich's book became a theoretical reference to reflect on the phenomenon of faith and how it is featured in the character Riobaldo, mystic and philosopher. Our general goal is to investigate an excerpt from the book: Riobaldo's faith, as portrayed in The Devil to Pay in the Backlands. Our specific goals discuss Paul Tillich's definition of faith, analyzes the religious aspects of Guimarães Rosa's main character, and understand Riobaldo's relations with the sacred and transcendent universe. Our methodology is based on bibliographic research. Through a literary review, we seek to deepen our knowledge of the work. For this purpose, we based our study in several authors and researchers, such as Antonio Candido and Walnice Galvão. Issues related to the country man's faith will be addressed. Besides, we will discuss the existence of faith and doubt. This article is an extension of our Master's Degree research, in which we investigated two short stories by João Guimarães Rosa in the light of Paul Tillich's theory. Keywords: Faith, Riobaldo, Till
\end{abstract}

\section{Introdução}

O trabalho busca compreender aspectos da fé do personagem de Guimarães Rosa em Grande Sertão: Veredas, o sertanejo e jagunço Riobaldo. Tentaremos definir como a fé aparece nesse personagem tão peculiar, tão ambíguo, ímpar, diferente e esquisito. A questão surgiu a partir da leitura do livro de João Guimarães Rosa, na disciplina de Mística Comparada, do curso de Especialização em Ciência da Religião. Além disso, fomos influenciados por aspectos da vida interior, contemplação, fé, mística, filosofia, teologia, transcendência e metafísica, abordados por Paul Tillich em Dinâmica da Fé (1985), cujo livro estava presente na bibliografia da disciplina de Filosofia e Teologia.

O tema que nos propomos investigar é a fé do personagem Riobaldo. O livro Dinâmica da Fé, de Paul Tillich (1985), será referência 
para o diálogo com o livro de Guimarães Rosa. A metodologia consiste em pesquisa bibliográfica. Por meio de revisão de literatura, buscaremos aprofundar a leitura da obra, utilizando como referência alguns autores, pesquisadores e comentadores, tais como Antônio Candido, Walnice Galvão, Manoel Cavalcanti de Proença etc.

A primeira leitura da obra icônica de Guimarães Rosa foi feita há mais de 20 anos, durante a graduação em Letras na Universidade Federal de Juiz de Fora. Na época, foram observadas as questões centrais acerca da linguagem e da presença de antíteses, paradoxos, neologismos e onomatopeias na obra do autor.

Vinte anos depois, a obra de Guimarães Rosa foi relida na disciplina Mística Comparada, durante uma pandemia de Covid-19. Esta pode ser comparada à epidemia de varíola presente no livro Grande Sertão: Veredas. Outros aspectos da obra foram emergindo: em especial, o tema da fé de Riobaldo. Assim, pretende-se refletir sobre a fé, a metafísica, a mística, a contemplação e a vida interior, presentes na construção do personagem Riobaldo, abordando a questão do bem e do mal, da dúvida e do amor, bem como de Deus e do Diabo. Naquela época, o objetivo não era perceber os espaços transcendentes assinalados por Manoel Cavalcanti de Proença (1958), que poderiam levar à análise do místico Riobaldo, possuidor de características que permitem que seja classificado como poeta, filósofo, místico, sertanejo, contemplador da natureza e professor, tal como foi chamado por Zé Bebelo, após ter compartilhado seus ensinamentos na fazenda. Walnice Nogueira, em seu texto Riobaldo, homem das metamorfoses (2001, p. 242), define Riobaldo como um espírito contemplativo, inquisidor, reflexivo e atento aos mistérios do mundo...

Segundo Antônio Magalhães (2009, p. 249), as palavras correspondem à força da experiência, à precisão, ao alcance da nomeação e à coragem de escrever sobre o mistério da vida. Assim, é possível afirmar que a beleza da revelação está presente tanto nos textos fundantes da fé e das religiões quanto em diversas obras literárias.

Em Grande Sertão: Veredas, há a seguinte frase: “Deus é paciência” (GUIMARÃES ROSA, 1994, p. 17). Também na Bíblia, Deus é chamado de paciente e amoroso, tal como afirmado em I Coríntios 13, 4 (“A caridade é paciente") e em I João 4, 8 ("Deus é Amor"). 
Com paciência, caminhamos nas veredas desse sertão e adentramos na vida de Riobaldo, que nos leva ao encontro da nossa própria vida. Rosa (1994, p. 5) nos expõe das Gerais, com coragem: o gerais corre em volta. Esses gerais são sem tamanho. Enfim, cada um o que quer aprova, o senhor sabe: pão ou pães, é questão de opiniães... O sertão está em toda a parte. [...]" "Deus é alegria e coragem - que Ele é bondade [...]" (GUIMARÃES ROSA, 1994, p. 440). O sertão é o mundo.

De acordo com Tillich (1985, p. 5), a "fé é estar possuído por aquilo que nos toca incondicionalmente". A leitura dessa obra descortinou, assim, um cenário próprio para o tema da fé, para a análise da "ambiguidade metafísica", tal como descrita por Antônio Candido, e também a importância do espaço, do Rio São Francisco e a observação da vida sertaneja, em suas rezas, contação de casos na roda da fogueira, cultos à Nossa Senhora (em especial, à Nossa Senhora da Abadia) e paixão pela coisa e pelo nome, conforme apontada nos estudos de Ana Maria Machado (2003). Através da obra de Guimarães Rosa, é possível adentrar na psicologia do rústico, em que tudo se transforma em significado universal graças à invenção (Antônio Candido, 2002, p. 122).

A questão que nos moveu nessa pesquisa consiste em determinar se existe fé em meio à dúvida, visto que Riobaldo vive entre Deus e o Diabo, e o livro deixa sempre questões em suspenso. Mais do que respostas, traz muitas perguntas: "o amor? Pássaro que põe ovos de ferro" (Idem). O amor é presença importante em meio à guerra e ao ódio, assim como a coragem.

Nosso objetivo geral é investigar um recorte do livro: o personagem Riobaldo e sua fé. Os objetivos específicos consistem em analisar, a partir da definição de fé de Paul Tillich (1985), aspectos religiosos e relações com o sagrado e o transcendente na fé do místico, filósofo e professor Riobaldo, personagem sempre atento ao mundo e seus mistérios, como aponta Galvão.

O trabalho será organizado por esta breve introdução e desenvolvimento das ideias relacionadas à fé do personagem e aos aspectos religiosos encontrados na obra. Além disso, serão apresentadas definições breves de conceitos e estabelecidas relações com o filósofo e teólogo, referencial teórico para este trabalho e pesquisadores contemporâneos. Não faremos, do livro de Rosa, um resumo linear, do início ao fim. Destacamos, 
no entanto, apenas os aspectos que apresentaram recortes importantes para este estudo. Finalmente, na conclusão, julgaremos se é possível ou não confirmar a hipótese de Riobaldo ser um sertanejo e jagunço de fé, mesmo em meio a tantas dúvidas e ambiguidades. O trabalho resultou na continuação dos estudos no mestrado tendo como referencial teórico Paul Tillich e dois contos de Rosa como objeto de pesquisa.

\section{Desenvolvimento}

O trabalho será desenvolvido a partir de pesquisa bibliográfica. Utilizaremos, como fundamentação teórica para pesquisar a fé de Riobaldo, o livro de Paul Tillich, Dinâmica da Fé (1985). A partir dos conceitos abordados no livro, analisaremos a fé do personagem Riobaldo, o narrador protagonista do romance de Guimarães Rosa, Grande sertão: Veredas, publicado em 1956. Como um "monstro", ele emergiu intempestivamente na discreta, ordeira e suficientemente autocentrada vida cultural brasileira, então em plena euforia político desenvolvimentista (SANTIAGO, 2018, s.p.).

Antonio Candido (1971, p. 134) sugere que "o livro é repleto de ambiguidade metafísica", envolvendo tanto Riobaldo quanto todos nós. Tal ambiguidade é geográfica, espacial, afetiva e amorosa: de um lado, há o amor sagrado de Otacília; de outro lado, o amor profano da encantadora Nhorinhá. Isto é, há as faces permitida e interdita do amor. Há, também, a suprema ambiguidade da mulher-homem que é Diadorim, além da ambiguidade metafísica, entre Deus e o Diabo, realidade e dúvida do pacto. Estes são os diversos planos de ambiguidade que compõem uma fusão de contrários, formando uma dialética extremamente viva que nos envolve a todos.

Os rios tratados na história são apresentados com nomes interessantes: temos o Dominguinhos, o Soninho e o principal, com nome de Santo, o São Francisco, que nos remete à lembrança daquele Santo da Idade Média, que recebeu, segundo contam, as marcas de estigma de Cristo. A mística, a fé e a devoção aos santos também se encontram presentes nos nomes das fazendas: "Fazenda Santa Catarina fica perto do céu". Enfim, ler sobre o sertão de Guimarães Rosa é uma aventura: "tem saudade de ideia e saudade de coração" (GUIMARÃES ROSA, 1994, p. 31). 
Assim, como Riobaldo, estamos cercados de vida e morte na pandemia, que revelou o mundo em ambiguidade, paradoxos e antíteses. No entanto, fazemos a travessia, assim como Riobaldo. O livro nos leva a uma natureza que já não é mais apenas do sertão, mas também fantasia e ficção. Ao lê-lo, ouvimos o canto dos pássaros, imaginamos a guerra e fazemos uma viagem ao nosso interior. Durante um momento em que não podemos ir para lugar nenhum, devido à guerra contra um inimigo invisível, um vírus, aproveitamos para viajar junto de Riobaldo nessa estranha saga no sertão, em meio a outros tantos sertanejos e sertanejas que surgem com suas histórias e casos.

\subsection{Os personagens}

Os personagens surgem como uma corredeira, com toda a sua força... "O diabo vige dentro dos homens" (GUIMARÃES ROSA, 1994, p. 7). O diabo é um dos personagens e vige nos homens. Viger, do latim vigere, é verbo intransitivo, significando vigorar, possuir eficácia, estar em vigor. Outra passagem significativa é aquela em que se afirma: "amor vem de amor" (GUIMARÃES ROSA, 1994, p. 27). Sem amor, não vivemos. São João, na sua Primeira Carta, nos lembra que não é possível amar a Deus sem amar aos outros.

Paul Tillich (1985, p. 15), por sua vez, analisa a relação contraditória entre fé e religião: "O perigo da fé é a idolatria, e a ambiguidade do sagrado resulta de sua possibilidade demoníaca. Nossa preocupação última - aquilo que nos toca incondicionalmente pode nos destruir assim como também nos pode curar. Mas sem uma preocupação última não podemos viver". Ambiguidade e contradição. A religião é uma contradição, paradoxo, assim como o sertão, o homem, o mundo, a vida e o amor. Riobaldo nos ensina sobre Deus: "Ele faz é na lei do mansinho - assim é o milagre. E Deus ataca bonito, se divertindo, se economiza [...] não ache que religião afraca. Senhor ache o contrário [...]. Mocidade" (GUIMARÃES ROSA, 1994, p. 25).

Os nomes de lugares (rios, fazendas etc.), animais e pessoas estão relacionados à narrativa e ao espaço da narrativa. Esse espaço já não é o "sertão real", mas aquele ficcional, onde o real e o imaginário se misturam, o que pode ser verificado na linguagem criada por Guimarães Rosa. Willi Bolle (1998), em ensaio, discorre acerca do espaço do 
sertão. Focalizando um micromodelo do sertão, o "Liso do Sussuarão", esse ensaio estuda a construção da paisagem em Grande Sertão: Veredas como componente de um retrato do Brasil. Partindo do confronto entre geografia inventada e geografia real, a tese rosiana do sertão é examinada como um "pensamento", que "se forma mais forte do que o poder do lugar" (BOLLE, 1998). Em seu texto, Bolle debate o espaço descrito no livro, dando continuidade à reflexão que iniciamos anteriormente sobre a questão do espaço e tempo na narrativa. Segundo Bolle (1988, p. 262), “o narrador retira pedaços reais do sertão e os recompõe livremente de maneira análoga aos mapas mentais que nascem da memória afetiva, de lembranças encobridoras, de pedaços de sonhos e fantasias, medos e desejos".

Quanto às lembranças, uma das mais significativas aparece na seguinte passagem: "Soflagrante conheci. [...] Os velhos verdes, semelhantes grandes lembrável das compridas pestanas, a boca melhor bonita, o nariz fino, afilhadinho [...]" (GUIMARÃES ROSA, 1994, p. 188). A linguagem é cheia de riquezas e neologismos. O livro é rico no poder da linguagem, já que o autor emprega uma gama imensa de recursos estilísticos, incluindo onomatopeias, que indicam os sons dos animais e das coisas. Dentre os personagens que chamam atenção para a questão mística da fé, podemos citar, além dos dois protagonistas, Reinaldo e Riobaldo, outros personagens, tais como Zé Bebelo e Compadre Quelemém.

Em Dinâmica da Fé (1985, p. 5), Tillich indaga a respeito da fé: “O que é a fé? Quais tipos? Fé é estar possuído por aquilo que nos toca incondicionalmente". Já mais adiante, o autor reflete sobre o êxtase que é estar fora de si, sem deixar de ser agente. Ele afirma que todo ato de fé contém elementos cognitivos e que a fé mística pode ser encontrada nas profundezas da pessoa, no lugar do infinito. Grandes místicos eram também grandes filósofos. Podemos considerar Riobaldo filósofo e místico?

Para Eduardo Gross (2013, p. 9), analisar a fé em Paul Tillich é uma tarefa importante, pois se trata de um conceito fundamental para o entendimento de sua obra, oferecendo, ao mesmo tempo, possibilidades interessantes para a interpretação da situação humana em geral e da 
vivência religiosa em particular. Dentre os tipos de fé abordados por Paul Tillich (1985), abordaremos a fé mística.

\subsection{A mística da fé}

O que é mística? O autor Henrique C. Lima Vaz (2000, p. 10) define o termo como uma forma superior de experiência de natureza religiosa ou religiosa-filosófica (Plotino), que se desenrola normalmente num plano transracional, além da razão que, no entanto, mobiliza as mais poderosas energias psíquicas do indivíduo. Orientadas pela intencionalidade própria dessa original experiência que aponta para uma realidade transcendente, essas energias elevam o ser humano às mais altas formas de conhecimento e de amor as quais lhe são dadas alcançar pela vida.

Paul Tillich (1985, p. 43), por sua vez, expõe que a fé mística é aquela em que o próprio místico sabe da distância entre o finito e o infinito, conformando-se com uma vida em que a união extática com o infinito é apenas raramente, ou mesmo jamais, alcançada. E o crente só pode ter fé, na medida em que é possuído por aquilo que o toca incondicionalmente. A fé mística é, como o sacramentalismo, um tipo de fé, não o contrário de fé. E, em todo tipo de fé, há um elemento místico, bem como um elemento sacramental.

$\mathrm{O}$ amor é importante para a religião, para a mística, para a fé. Em Grande Sertão: Veredas, a busca pelo amor é expressa através das experiências de Riobaldo: "[...] como eu tivesse os mais amores!" (GUIMARÃES ROSA, 1994, p. 238). A descoberta do amor pela natureza também pode ser percebida pelo olhar "verde" de Diadorim (olhos verdes de Reinaldo): o olhar que fotografa a beleza das flores e dos pássaros, que nos faz pensar nas pessoas como anjos, ou demônios, as quais podem suscitar coisas boas ou ruins em nós, nos influenciando. O amor é a reunião do que está separado. Nesta aspiração de comunhão e na relação da fé com amor, Tillich $(1985$, p. 74-75) afirma a resposta à pergunta anterior por ele formulada: "Existe algo como amor sem fé?" E responde mais adiante que a fé como aquilo que nos toca incondicionalmente inclui o amor, seja entre Deus e o homem seja entre duas pessoas.

Por isso, Riobaldo fala sobre os afetos, o olhar de Diadorim e a lembrança da mãe: "eu respondi. Os afetos. Doçura do olhar dele 
me transformou para os olhos de velhice da minha mãe. Então, eu vi as cores do mundo" (GUIMARÃES ROSA, 1994, p. 203). A mãe e Diadorim são como anjos para Riobaldo, anjos da guarda que ensinam sobre Deus: "Diadorim era quem tinha me ensinado [...] Molhei mão em mel regrei minha língua. Aí, falei dos pássaros, [...]Aquela visão dos pássaros, aquele assunto de Deus, Diadorim era quem tinha me ensinado" (Idem). O amor está atuando em todo ser humano, mesmo que profundamente oculto, pois todo ser humano aspira à união com o fundamento último do ser (Tillich, 1985, p. 74). Portanto, Riobaldo expressa uma aspiração paradoxal da fé, assim como a vida é paradoxal, no sertão. Em meio a guerra, há a busca pela união, amor, mas também se isola em alguns momentos, o que não significa separação.

Quando se encontrava em situações de perigo, lembrava dos amores (Diadorim e Otacília). O autor Manoel Cavalcanti Proença (1958, p. 160) discorre de forma objetiva sobre as andanças e os combates, criadores da personalidade do jagunço que termina chefe do bando, e, de forma subjetiva, sobre as marchas e contramarchas de um espírito estranhamente místico. Esse espírito estranhamente místico é o que nos interessa. Místico, contemplativo e inquiridor. Riobaldo é cheio de vivência interior, de modo que, ao ler Grande Sertão: Veredas, somos levados a pensar em filosofia, psicologia, vivência interior e contemplação da natureza. Riobaldo, ao se lembrar de Otacília ou de Diadorim, pensa em anjos em meio a lutas e contempla a natureza. Os amores são simbolizados pelas mulheres em meio à violência e às situações de perigo do sertão (ser- tão). Paradoxo expresso da fé e da vida de um ser tão ímpar, inquisidor, reflexivo e atento aos mistérios do mundo. Riobaldo é capaz de captar o sentido infinito, incondicional, pois onde há a fé, há também experiência do que é sagrado.

Riobaldo aprende sobre o ser homem, humano, e Diadorim ensina-o a ter coragem: "carece de ter coragem [...]. Ah, tem lances, esses - se riscam tão depressa, olhar da gente não acompanha. Urutu dá e já deu o bote? Só foi assim. Mulato pulou para trás, ô de um grito, gemido urro" (GUIMARÃES ROSA, 1994, p. 146). Diadorim ataca como o urutu, a cobra que pica rapidamente, e se defende do agressor. O ódio que Reinaldo/Diadorim carrega passa a se fazer presente na vida de Riobaldo também, assim como o amor. Como diz Antonio Candido 
(2002, p. 134), a face interdita do amor é simbolizada na suprema ambiguidade da mulher-homem que é Diadorim, ambiguidade metafísica. Com Diadorim, Riobaldo aprende coisas de Deus e do Diabo. E, com compadre Quelemém, filosofa, experimenta coisas de Deus e do homem. São esses os dois mestres da amizade de Riobaldo, que lhe ensinam coisas da vida, do sertão, das veredas. O ódio de Reinaldo/Diadorim aumenta com a morte de seu pai, Joca Ramiro, morto pelas costas pelas mãos de Hermógenes, o judas, aquele que tinha feito um pacto com o diabo. A coragem é muito importante para a fé de Riobaldo, essa lição aprendida com Diadorim. Tillich (1985, p. 66) expõe sobre a coragem que não nega a dúvida, confessa-se apesar da dúvida. A coragem não precisa de uma convicção inquestionável, ela engloba o risco sem o qual não é possível qualquer vida criativa. Válida para a fé viva.

Paul Tillich, no seu livro A dinâmica da fé (1985, p. 66), trata da dúvida que não é superada pela repressão, e sim pela coragem. A coragem não nega que a dúvida está aí; mas ela aceita a dúvida como expressão da finitude humana e se confessa, apesar da dúvida, àquilo que toca incondicionalmente. A coragem é um elemento importante para a fé, a qual está presente em outro livro de Paul Tillich, A coragem de Ser (1952), em que a coragem é descrita como ato humano. É a coragem que Diadorim ensina no encontro lembrado nas águas do rio São Francisco, o que marcaria toda a vida de Riobaldo. Diadorim ainda ensina a olhar a natureza ("manuelzinho da croa sempre em casal") e a cuidar de si "dependurou o espelho num galho. [...] Desde esse dia, por animação nunca deixei de cuidar de meu estar" (GUIMARÃES ROSA, 1994, p. 199).

O antagonista, por ser o personagem que se contrapõe, é Hermógenes: "homem sem anjo da guarda" (GUIMARÃES ROSA, 1994, p. 283). Mas é o mesmo que, na hora da guerra, passa o fumo na água ardente para espantar os mosquitos e dá para Riobaldo: "os mosquitos te deixam de ferroar" (Idem). Tanto o mal quanto o bem estão presentes no livro: "O mal ou o bem, estão é em quem faz; não é no efeito que dão" (GUIMARÃES ROSA, 1994, p. 130) "Sou o moço professor. [...] alegria dele, me ouvindo, foi estupefacta" (GUIMARÃES ROSA, 1994, p.177). Riobaldo foi professor de Zé Bebelo e o secretariou, anotando em "um caderno grosso para por ordem dele assentar, nomes, números 
[...]" (Idem). Faustino Teixeira (2020) explana sobre Riobaldo, objetivando "captar o traço espiritual de Riobaldo". Os nomes utilizados no livro têm importância: Zé Bebelo deu-se esse apelido por causa de um jagunço, Joãozinho Bem-Bem, das Aroeiras. A presença do termo "bem" no nome de um de seus personagens mais encantadores é significativa. Por outro lado, Diadorim revela que seu nome não é Reinaldo e pede segredo a Riobaldo: Dia... diabo... dor... Diadorim... dia...divina... Maria Deodorina da Fé Bettancourt Marins, nome de Diadorim revelado ao final, percebe-se Maria Deodorina da Fé, a fé presente nas marcas no nome.

A teologia, a filosofia e a mística coexistem no livro todo de Rosa. Segundo Ávila (2010, p. 107), a mística expressa a linguagem de todas as religiões e de todos os saberes, no sentido mais pleno do termo. $\mathrm{O}$ autor alerta, também, para a existência de dois tipos de mística: a extrovertida e a introvertida. Em Grande Sertão: Veredas essa confluência de "crenças religiosas" é refletida pela variedade de sentidos religiosos expressos pelos personagens e pela mística que se evidencia na singularidade da linguagem de Rosa.

Reinaldo é homem para Riobaldo, mas também amigo e amor. Para o leitor, entretanto, há a presença da ambiguidade mulher-homem, que aparece nos detalhes, no cuidar, no olhar e nas feições; tal ambiguidade transparece na lembrança daquelas mãos, de como se encostava no rosto de Riobaldo ao cortar seu cabelo.

Já em outro momento, na solidão, Riobaldo afirma: "Nem a pessoa especial do Reinaldo não me ajudava. Sozinho sou, sendo, de sozinho careço" (GUIMARÃES ROSA, 1994, p. 210). Nesse momento, Riobaldo lembra-se de compadre Quelémem, que lhe ensinou a dar tudo a Deus, em uma espécie de reza:

Diz ele; eu creio. Mas ensinou que, maior e melhor, ainda, é, no fim, se rejeitar até mesmo aquele desejo principal que serviu para animar a gente na penitência de glória. E dar tudo a Deus, que de repente vem, com novas coisas mais altas, e paga e repaga, os juros dele não obedecem medida nenhuma. Isso é do compadre meu Quelemém. Espécie de reza? (GUIMARÃES ROSA,1994, p. 211).

Essa “Espécie de Reza?” pode ser a presença da fé na penitência, no jejum, no desprender-se, no entregar-se a Deus: "dar tudo a Deus 
que de repente vem, com novas coisas mais altas" (Idem). A presença da fé, na hora da solidão, do desespero e da dificuldade, aparece no livro como a mística, a metafísica e a transcendência, através de orações, rezas, alusões à Nossa Senhora, em especial à Nossa Senhora da Abadia, e da "Jaculatória de São Bento". "Nenhum ser humano é capaz de viver sem uma preocupação última”. (TILLICH, 1985, p. 66) Riobaldo percebe os símbolos, e se não fosse expressa por símbolos, a fé não seria expressão da dupla característica do fundamento e abismo da realidade. Por isso, Riobaldo expressa a fé e como ela é ambígua, paradoxal. E nos momentos de solidão, não significa fora da comunidade, mas, "vida da fé é vida na comunhão da fé" (TILLICH, 1985, p. 76); importante seu isolar que não é separação, afastamento, mas também um crescimento, renovação da comunidade, segundo Tillich (1985, p. 77) não existe vida de fé que não seja vida na comunhão; isso também vale para a solidão do místico enquanto ele ainda fala a linguagem da comunhão de fé. Tanto a fé quanto a dúvida estão presentes no homem. Riobaldo expressa um ato de fé, ato que é realizado por um ser finito, que está tomado pelo infinito e para este se volta nesta "espécie de reza". Trata-se de um ato no âmbito do finito, com toda a limitação que, como tal, lhe é própria; mas também é um ato do qual participa o infinito, transcendendo os limites do finito. Fé é certeza, na medida em que ela se baseia na experiência do sagrado (TILLICH, 1985, p.15). Podemos dizer que Riobaldo experiencia o infinito, no seu finito. Experiência do Sagrado, mesmo em meio às dúvidas. Mesmo nos santos, a dúvida aparece (TILLICH, 1985, p. 66).

Mas uma vez que nenhum ser humano é capaz de viver sem uma preocupação última, tanto fé como dúvida sempre estão por natureza presentes no homem. Fé e dúvida têm sido colocadas como opostos, exaltando-se a certeza da fé como o fim de toda dúvida. É verdade que existe semelhante serenidade muito além das agitadas lutas: entre fé e dúvida; e alcançar esse estado é um desejo natural e justo. Mas mesmo quando ele é atingido - como, por exemplo, por santos ou por pessoas que estão firmes em sua fé -, nunca está ausente o elemento da dúvida. Nos santos a dúvida aparece, como o mostram as lendas em torno dos santos, sob a forma de tentação, a qual aumenta na medida em que cresce a santidade (Idem). 
Podemos dizer que há um caminho para a santidade no livro Grande Sertão: Veredas? O caso de Maria Mutema (GUIMARÃES ROSA, 1994, p. 307 -315) trata do perdão: perdão pelo assassinato de seu marido. O que mais chama a atenção é o perdão do povo. Os missionários foram instrumento de Deus pela pregação e revelação dos pecados. Ela jogou chumbo derretido no ouvido do marido, sem motivo algum, mentindo ao padre durante a confissão e dizendo-lhe que havia enlouquecido por amor: "por enjoar do Padre Ponte, também sem ter queixa nem razão, amargável mentiu, no confessionário: disse, afirmou que tinha matado o marido por causa dele, Padre Ponte - porque dele gostava em fogo de amores". No entanto, ela, ao final, alcança o perdão do povo, sendo tida como um tipo de santa.

Ainda sobre essa temática, podemos remeter ao início do livro, em que Zé Bebelo perdoa os irmãos que mataram o pai: "perdoar é sempre o justo e certo". Também a presença de Nossa Senhora é evocada nesse trecho do perdão:

Pois, se ela perdoa ou não, eu não sei. Mas eu perdôo, em nome dela - a Puríssima, Nossa Mãe!" - Zé Bebelo decretou. - "O pai não queria matar? Pois então, morreu - dá na mesma. Absolvo! Tenho a honra de resumir circunstância desta decisão, sem admitir apelo nem revogo, legal e lealdado, conformemente!..." Aí mais Zé Bebelo disse, como apreciava: - "Perdoar é sempre o justo e certo... (GUIMARÃES ROSA, 1994, p. 99).

Maria Mutema foi assassina, o mal estava com ela, mas não permaneceu com ela. Após a pregação dos missionários, que pode ter parecido dura, em um primeiro momento, ela se arrepende. De toda forma, toda aquela tragédia serviu para a salvação e arrependimento de Maria Mutema. Para Paul Tillich (1985), ter fé é estar possuído por aquilo que nos toca incondicionalmente, remetendo à verdade e ao compromisso:

E Maria Mutema, sozinha em pé, torta magra de preto, deu um gemido de lágrimas e exclamação, berro de corpo que faca estraçalha. Pediu perdão! Perdão forte, perdão de fogo, que da dura bondade de Deus baixasse nela, em dores de urgência, antes de qualquer hora de nossa morte. E rompeu fala, por entre prantos, ali mesmo, a fim de perdão de todos também, se confessava. Confissão edital, consonantemente, para tremer exemplo, raio em pesadelo de quem ouvia, público, que rasgava gastura, como porque avessava a ordem das coisas e o quieto comum do viver 
transtornava. Ao que ela, onça monstra, tinha matado o marido - e que ela era cobra, bicho imundo, sobrado do podre de todos os estercos. Que tinha matado o marido, aquela noite, sem motivo nenhum, sem malfeito dele nenhum, causa nenhuma; porque, nem sabia. Matou - enquanto ele estava dormindo - assim despejou no buraquinho do ouvido dele, por um funil, um terrível escorrer de chumbo derretido. (GUIMARÃES ROSA, 1994, 312-313)

Percebemos, nessa forte cena de Maria Mutema, a fé do povo sertanejo e a presença de um Deus misericordioso, tal como anunciado nos evangelhos. Paulo Apóstolo aborda da seguinte maneira a questão da salvação e da fé, em Romanos 1, 16: "Na verdade, eu não me envergonho do evangelho: ele é força de Deus para a salvação de todo aquele que crê". E a fé, para Paulo, é acreditar em tudo aquilo que ainda não vemos, ter esperança no que ainda não vemos (HEBREUS, 11, 1). Em Colossenses 1, 4-5, acrescenta: "Em fé, amor e esperança". Esperança e fé são expressões do sertanejo em meio ao ódio da guerra, manifestando o perdão e o amor de Deus.

Contudo, na obra de Guimarães Rosa, o personagem diabo também é presente. Santo Agostinho, no livro Confissões, indaga sobre o mal: "Onde está pois o mal? Donde e por onde logrou ele penetrar? Qual é a sua raiz e qual é sua semente? Ou será que não existe?". Assim também em João 8, 43, discute-se sobre o mal, sobre o diabo que é definido como homicida e mentiroso. Em uma conversa entre Riobaldo e João Bexinguento, o assunto sobre o mal como em Agostinho e em João sobre o tema o mal, o diabo chega ao caso de Maria Mutema. Após a guerra, ambos manifestam insônia e se perguntam: "mas a gente estava com Deus?" (GUIMARÃES ROSA, 1994, p. 306). João Bexiguento, Riobaldo mataram, lutaram no sertão e Riobaldo e João conversam ao redor da fogueira após a guerra com insônia depois do agito da luta e se questionam. Para João Bexiguento, Deus e o diabo encontram-se bem separados, enquanto para Riobaldo talvez os dois misturados...Teria João Bexiguento uma fé diferente daquela de Riobaldo? Riobaldo teria uma fé paradoxal, ambígua na qual se questiona se estava ou não estava com Deus. Deus estava ou não estava com eles...coragem...fé...vida, as veredas, o sertão se estava com Mutema estava também com eles. Ao mesmo tempo surgem definições de Deus, na narrativa, no livro, Deus 
é alegria e coragem - que Ele é bondade (...) (GSV, 1994, P.440) E a fé de Riobaldo se mostra em meio ao Sertão, ser tão único, inquiridor, místico, professor filósofo Riobaldo como uma fé paradoxal como é também a narrativa do livro e a própria vida.

O livro inicia com a palavra NONADA e termina com essa palavra quase na última linha. O nada nunca é um fim, é um recomeço. "Deus é paciência. [...] o gerais corre em volta. Esses gerais são sem tamanho. Enfim, cada um o que quer aprova, o senhor sabe: pão ou pães, é questão de opiniães... O sertão está em toda a parte" (GUIMARÃES ROSA, 1994, p. 5). "A eternidade é o fundamento e o objetivo de todo ser, pois Deus será tudo em todos". (TILLICH, 2020, p. 80). Percebe-se que a necessidade de viver esta fé mesmo paradoxal como a própria vida de Riobaldo e a nossa em meio ao dia a dia, dúvidas e caminhos, veredas e a preocupação última se apresenta na personagem.

\section{Considerações finais}

Podemos dizer que há um caminho, uma vereda para a eternidade, para a santidade, no livro de Guimarães Rosa? É possível ter fé em meio às dúvidas. Percebemos a sutileza de símbolos, linguagens e demonstrações da fé do sertanejo em Riobaldo. Nossa Senhora da Abadia, presente nos momentos de tentação de toda a comunidade, encontra-se nas orações de compadre Quelemen e de Otacília representando e simbolizando a comunhão.

Como não ter Deus? Deus existe mesmo quando não há... Mas o demônio não precisa existir para mover a gente sabendo que ele não existe ele toma conta de tudo. [...] Deus é alegria e coragem - que Ele é bondade [...]. E nós, então, cada um depois dum, viemos ao quarto-do-oratório beijar a santa maior [...] Minha Nossa Senhora mãe de todos (GUIMARÃES ROSA, 1994). 


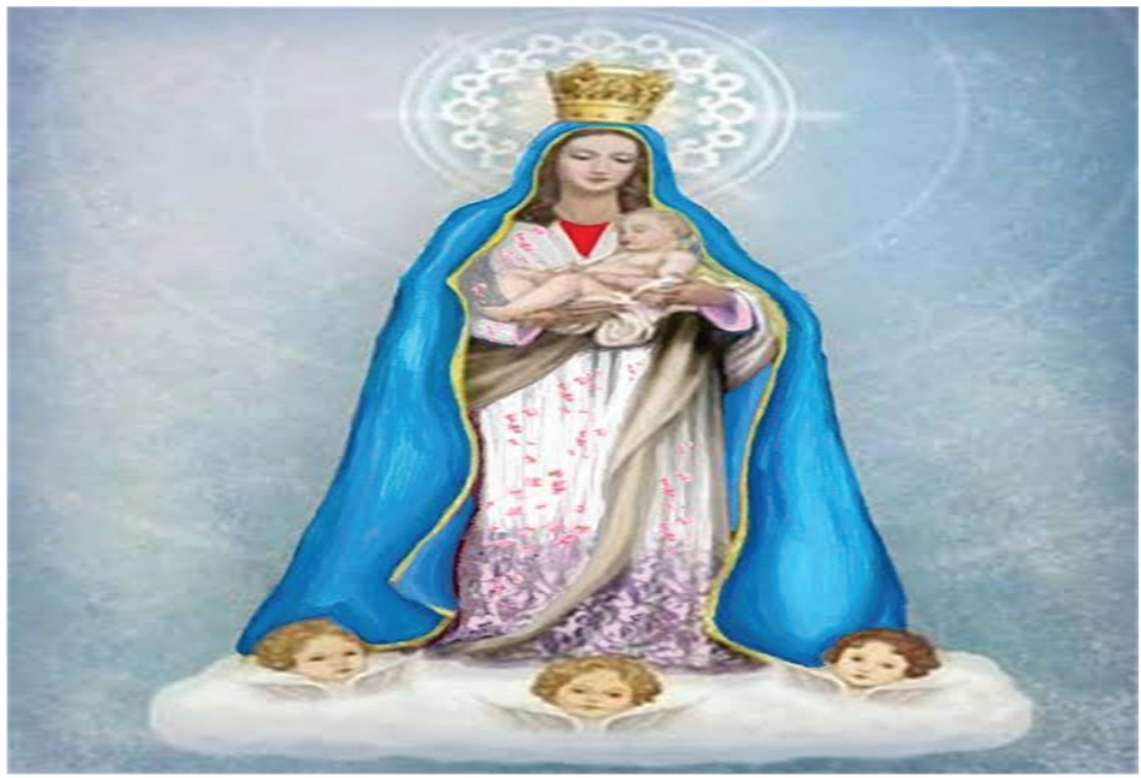

Segundo Paul Tillich, a dúvida não impede a fé e, mesmo os Santos enfrentaram-na. "Como não ter Deus? Deus existe mesmo quando não há". No seu caminho a tentação, o diabo; a dúvida e o tudo presentes no nada. Paradoxos, ambiguidades, ilustrados no objeto de análise deste artigo: o personagem Riobaldo e a sua fé.

Fonte: Nossa Senhora da Abadia.

Disponível em: https://missaosementes.com.br/conheca-a-devocao-a-nossa-senhora-daabadia/. Acesso em: set. 2020

\section{Referências}

AGOSTINHO. Confissões. Versão online digitada por Lucia Maria Csernik, 2007. Disponível em: https://img.cancaonova.com/noticias/pdf/277537_SantoAgostinho-Confissoes.pdf. Acesso em: nov. 2020.

AVILA, Antonio. Para conhecer a psicologia da religião. São Paulo: Edições Loyola, 2007.

BÍBLIA - Bíblia de Jerusalém. São Paulo: Paulus, 2002.

BOLLE, Wille. O Sertão como Forma de Pensamento. SCRI PTA, Belo Horizonte, v. 2, n. 3, 1998.

\section{Literatura Fundamental 42: Grande Sertão: Vere-}

das. UNIVESP TV, 2014. Disponível em: https://www.youtube.com/ watch? $\mathrm{v}=\mathrm{Jcfpbm} 7 \mathrm{owCo}$. Acesso em: set. 2020.

CANDIDO, Antonio. O homem dos avessos. Tese e antítese. São Paulo: Companhia Editora nacional, 1971. 
COUTINHO, Graciello Nascimento. O livre-arbítrio e o problema do mal em Santo Agostinho. In: PDDFArgumentos, ano 2, n.3, 2010.

GALVÃO, Walnice Nogueira. Guimarães Rosa. São Paulo: Publifolha, 2000. GUIMARÃES ROSA, João. Grande Sertão: Veredas. Rio de Janeiro: Editora Nova Aguilar, 1994.

GROSS, Eduardo Gross. O conceito de Fé em Paul Tillich. In: Revista Eletrônica Correlatio, v. $\square 12, \square$ n. $\square 23, \square$ jun. $\square 2013$. Disponível em: https://www. metodista.br/revistas/revistas-ims/index.php/COR/article/view/4196. Acesso em 12 out. 2021.

$\mathrm{KOCH}$, Isabelle. TheAgostinian definition of belief. In: $\square$ Síntese, $\square$ Belo Horizonte, $\square$ v. $\square 42$, n. $132,2015$.

MACHADO, Ana Maria. Recado do Nome: leitura de Guimarães Rosa à luz do nome de seus personagens. Rio de Janeiro: Nova Fronteira, 2003.

MAGALHÃES, Antonio. Deus no espelho das palavras: teologia e literatura em diálogo. São Paulo: Paulinas, 2009.

PINHEIRO, Marcus Reis. A mística e suas Histórias - o que é a Mística? Publicado em jul. 2020. Disponível em: https://www.youtube.com/ watch? $v=$ Tlfo1ONzxqM. Acesso em: set. 2020.

. Relação Deus - Homem - Êxtase e Entusiasmo. Publicado em jul. 2020. Disponível em: https://www.youtube.com/watch?v=TfjaqGV3ZKc. Acesso em: set. 2020

PROENÇA, Manoel Cavalcanti. Trilhas no Grande Sertão. In: Augusto dos Anjos e outros ensaios. Rio de Janeiro: MEC, 1958.

SANTIAGO, Silviano. Genealogia da ferocidade: ensaio. Recife: Editora Cepe, 2018.

TEIXEIRA, Faustino. Riobaldo e o roteiro de Deus Grande Sertão: Veredas. In: Vida Pastoral, a.61, n.334, jul. 2020.

Disponível em: https://www.vidapastoral.com.br/edicao/riobaldo-e-o-roteiro-de-deus-grande-sertao-veredas/Acesso em 12 out. 2021.

TILLICH, Paul. Dinâmica da fé. São Leopoldo, RS, Brasil: Editora Sinodal, 1985.

TILLICH, Paul. Textos selecionados. São Paulo: Fonte editorial, 2020.

VAZ, Henrique C. De Lima. Experiência Mística e Filosofia na Tradição

Ocidental. São Paulo: Edições Loyola, 2015.

Submetido em: 12-10-2021

Aceito em: 24-1-2022 